\title{
Palynological interpretation of the palaeoenvironments of Miocene strata of the well Igbomotoru-1, Niger delta
}

\author{
F.E. OBOH \\ Department of Geology and Geophysics, \\ University of Missouri, \\ Rolla, \\ Missouri 65401, U.S.A.
}

\author{
M.B. SALAMI \\ Department of Geology, \\ Obafemi Awolowo University, \\ Ile-Ife, Nigeria.
}

\author{
J.L. CHAPMAN \\ Department of Earth Sciences \\ Unizersity of Cambridge. \\ Downing Street, \\ Cambridge, $C B 23 E Q, U . K$.
}

\begin{abstract}
Palynological and lithological results have been employed in interpreting the depositional environment of strata penetrated by the Igbomotoru- 1 well at the interval $1123-3583$ metres. The environment of deposition is largely transitional with marine influence occurring only at the base of the studied sequence. Zonocostites ramonae is frequent to abundant in most samples: this indicates a high influence of mangrove swamp vegetation in the environment at the time of deposition. The absence or rarity of this species at some horizons within the studied interval is taken as evidence of deposition in a more continental environment or of a swamp forest area composed of non-Rhizophora type trees. The nature of the organic matter points to a source area near the basin of deposition for the sediments. J. micropalaeontol., 11 (1): 1-6 , June 1992.
\end{abstract}

\section{INTRODUCTION}

Studies on various aspects of the structure, sedimentology, stratigraphy and petroleum geology of the Niger delta have been published by several workers including Allen $(1964,1965)$, Frankl \& Cordry (1967), Short \& Stäuble (1967), Adegoke (1969), Weber (1971), Burke et al. (1971, 1972), Merki (1972), Murat (1972), Oomkens (1974), Weber \& Daukoru (1976), Asseez (1976), Evamy et al. (1978), Petters (1979), Ejedawe (1981), Lambert-Aikhionbare (1982), Lambert-Aikhionbare \& Shaw (1982), Ogbe (1982), Odigi (1987) and Bustin (1988). Despite the fact that exploration and exploitation have been going on in this petroliferous basin for several decades, there is relatively little published information on the palynology of the sediments. This lack of accessible information is probably due to the confidentiality of oil company reports.

The most comprehensive published work to date on the palynology of the Niger delta was carried out by Germeraad $e t$ al. (1968). The work involved the study of palynomorph assemblages of Tertiary sediments in some parts of tropical South America, Africa and Asia. Its primary purpose was to arrive at a better interpretation of the stratigraphy of those sedimentary basins where other means of correlation have failed. Other published works on the palynology in this area, covering the Late Cretaceous to Recent, are largely concerned with descriptions of palynomorphs and palynological zonations. However, some of them incorporated environmental interpretation in their studies (see van Hoeken-Klinkenberg, 1964, 1966; Clarke, 1966; Clarke \& Frederiksen, 1968; Knaap, 1971; Sowunmi, 1973, 1981; Legoux, 1978; Jan du Chêne \& Salami, 1978; Jan du Chêne et al., 1978 and Biffi \& Grignani, 1983).

This study of sidewall samples from Igbomotoru- 1 well in the Niger delta, aims at using both palynological and lithological data to interpret environmental conditions in the area of deposition as well as highlighting the problems often encountered in environmental reconstruction.

\section{SAMPLE SITE AND PREPARATION}

Well Igbomotoru-1 is located at latitude $4^{\prime \prime} 31^{\prime} 40.3^{\prime \prime} \mathrm{N}$ and longitude $6^{\circ} 03^{\prime} 29.6^{\prime \prime E}$ within the Niger delta (Fig. 1). It was drilled to a total depth of 4325 metres by the Shell Petroleum Development Company of Nigeria. The sediments vary from coarse clastics with occasional lignite streaks $(0-1590 \mathrm{~m})$ to finer clastics ( $1590-4325 \mathrm{~m})$. They have been grouped into four informal lithostratigraphical units designated A to D (Fig. 2) which were delineated on the basis of gamma ray $\log$ and sidewall sample descriptions (Oboh \& Salami 1989). These units correspond to the Benin and Agbada Formations which consist of continental sands and transitional sand and shale sediments described by Short \& Stäuble (1967). Three informal palynological subzones which are subdivisions of the Crassoretitriletes vanraadshooveni zone of Germeraad et al. (1968) have been established. Thesesubzones are Peregrinipollis nigericus (1123-1950m), Retitricolpites sp. $1(1950-2480 \mathrm{~m})$ and Clavamonocolpites sp. (2480-3583m ) [Fig.2; see also Oboh \& Salami 1989, for further details and photomicrographs of palynomorphs].

Forty-one sidewall samples were collected from shaly horizons from 1123-3583m depth which has been dated as Middle to Upper Miocene on the presence of cetain foraminifera and palynomorphs (Oboh \& Salami 1989). Samples of about $25 \mathrm{~g}$ were prepared by standard palynological techniques, including oxidation in nitric acid for a few minutes, and the unsieved residues were strew-mounted on slides. The total area under the cover slip of each slide was systematically studied under a Leitz Orthomat - $W$ binocular microscope and identification was attempted for as many forms as possible. Colouration and size of organic matter present were also determined.

\section{ENVIRONMENTAL RECONSTRUCTION}

A. Limitations to reconstruction of environment of deposition The main limitations which arise when reconstructing environments of deposition in deltaic sediments, like those in 


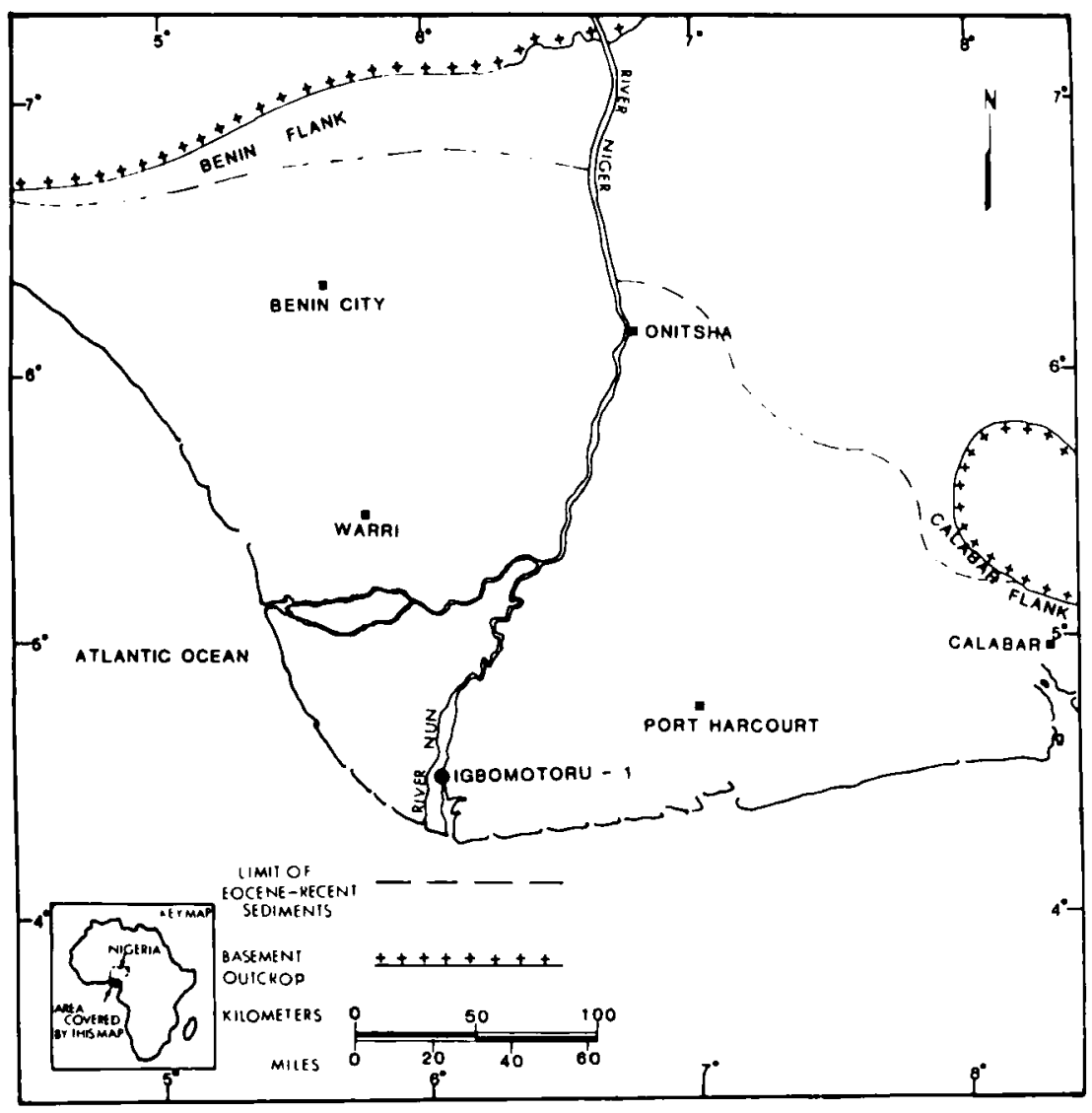

Fig. 1. Map of the Niger delta showing the location of the well Igbomotoru-1. has remained sufficiently close to the equatorial region, the polar advances of the Pleistocene have had a minimal effect on the flora, but the eustatic drop in sea level has resulted in the advance of the coastline (Fig. 3). This minimal effect of the Pleistocene is substantiated by the nearly uniform nature of the palynofloras in the deltaic sediments since Miocene and Pliocene times (Germeraad et al., 1968). Several pollen and spore types found in these sediments appear similar to those produced by the present vegetation zones and can therefore be used as indicators of past environments based on recent ecological information.

\section{B. Methods of interpretation}

Four features have been employed in this environmental interpretation. They are:

1. Association of some environmentally restricted marker species such as Crassoretitriletes vanraadshooveni, Magnastriatites howardi and Pachydermites diederixi.

2. Percentage of Zonocostites ramonae (Rhizophora type) in the total palynomorph sum.

3. Nature of organic matter in the sediments. 4. Lithological characters of the strata.

\section{Results of environmental study}

The distribution of some of the palynomorphs from the Igbomotoru-1 well samples is shown in Fig. 2. The various parameters employed in the interpretation of the environment of deposition are discussed as follows:

the Niger delta, come from the problems of contamination, and the interpretation of the data collected. Palynologists work with two types of samples: surface and subsurface samples. The latter can be further divided into three classes: (a) conventional cores, (b) sidewall cores and (c) ditch-cuttings. Both surface and subsurface samples are susceptible to contamination during collection, which in turn has negative effects on stratigraphical interpretations. Contamination may also occur during sample preparation from air- or water-borne pollen and spores or human error. Of the three sample types derived from oil wells, conventional cores are the most reliable because they are the least likely to be contaminated by drilling mud or caving of rock strata, whilst the ditch-cuttings are the least reliable for these reasons. In a situation in which ditch-cutting have to be used, the sampling interval may have to be increased to eliminate the problems due to caving. A sampling interval of $20-30 \mathrm{~m}$ is usually appropriate in such cases. Adequate care must be taken to see that sidewall cores are not contaminated by extraneous matter.

It is important to bear in mind whilst making palaeoecological deductions that climatic conditions and latitudes have changed through geological time (Germeraad et al., 1968, Smith et al., 1981). Despite the fact that the Niger delta has advanced seaward since its inception, its palaeocoastline in the Middle to Upper Miocene was not substantially different from the present position (see Fig. 3), and the present climatic conditions are considered similar to those of the Miocene (Weber, 1971). Since this delta
1. Environmental marker species. Many of the palynomorphs are closely similar in morphology to recent species so that assumptions can be made about their ecological requirements (Germeraad et al., 1968). For example, species indicative of coastal plain environments include Crassoretitriletes vanrandshooveni (a climbing fern of coastal swamp forest), Magnastriatites howardi (a small fern of open freshwater habitats), Pachydermites diederixi (an angiosperm of coastal swamps) and Zonocostites ramonae (the mangrove group). All four species are present throughout most of the sampled sequence although $M$. howardi is rather intermittent and rare. This last species, according to Germeraad et al. (1968), is dispersed mainly by water and the spore is likely to occur most frequently in inland environments whereas the distribution of $Z$. ramonae tends to be coastal and offshore marine. Therefore, the fairly high levels of $Z$. ramonae compared with the infrequent occurrence of $M$. howardisuggests that the sequence recorded here represents mainly a coastal environment of deposition or a marine situation where $Z$. ramonae has been transported offshore before deposition.

2. Percentage of Zonocostites ramonae. Z. ramonate is a distinctive pollen type found in extant genera of mangroves notably Rhizophora (Germeraad et al., 1968). Muller (1959), after study of recent deposition of pollen in and around the Orinoco delta, showed that Rhizophora produced abundant pollen which can be blown by wind over a wide geographical area. High perceńtages of Rhizophorn pollen occur close to the source and 


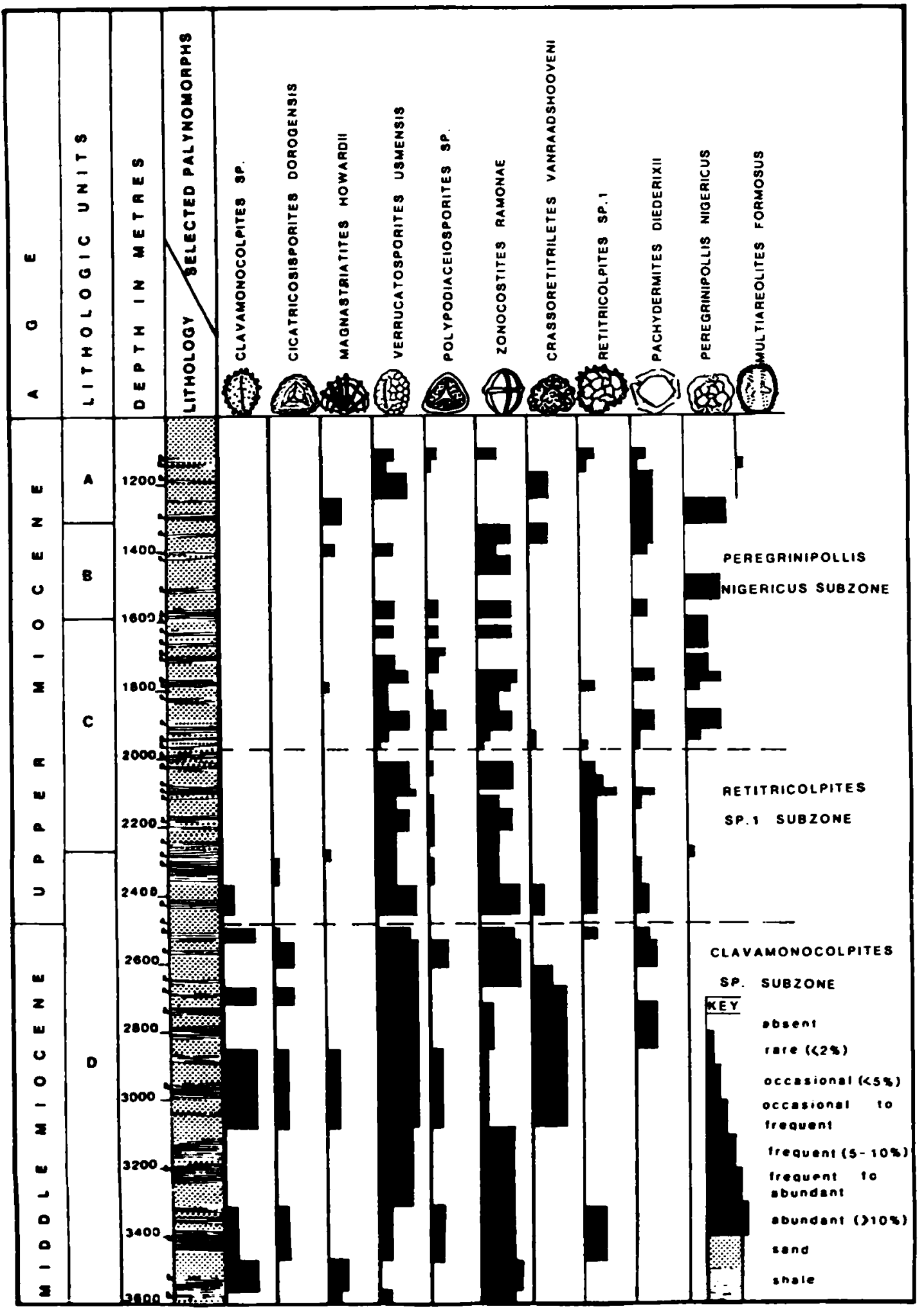

Fig. 2. Stratigraphic distribution of selected species. Figure also shows the depths at which samples were taken from the well. 


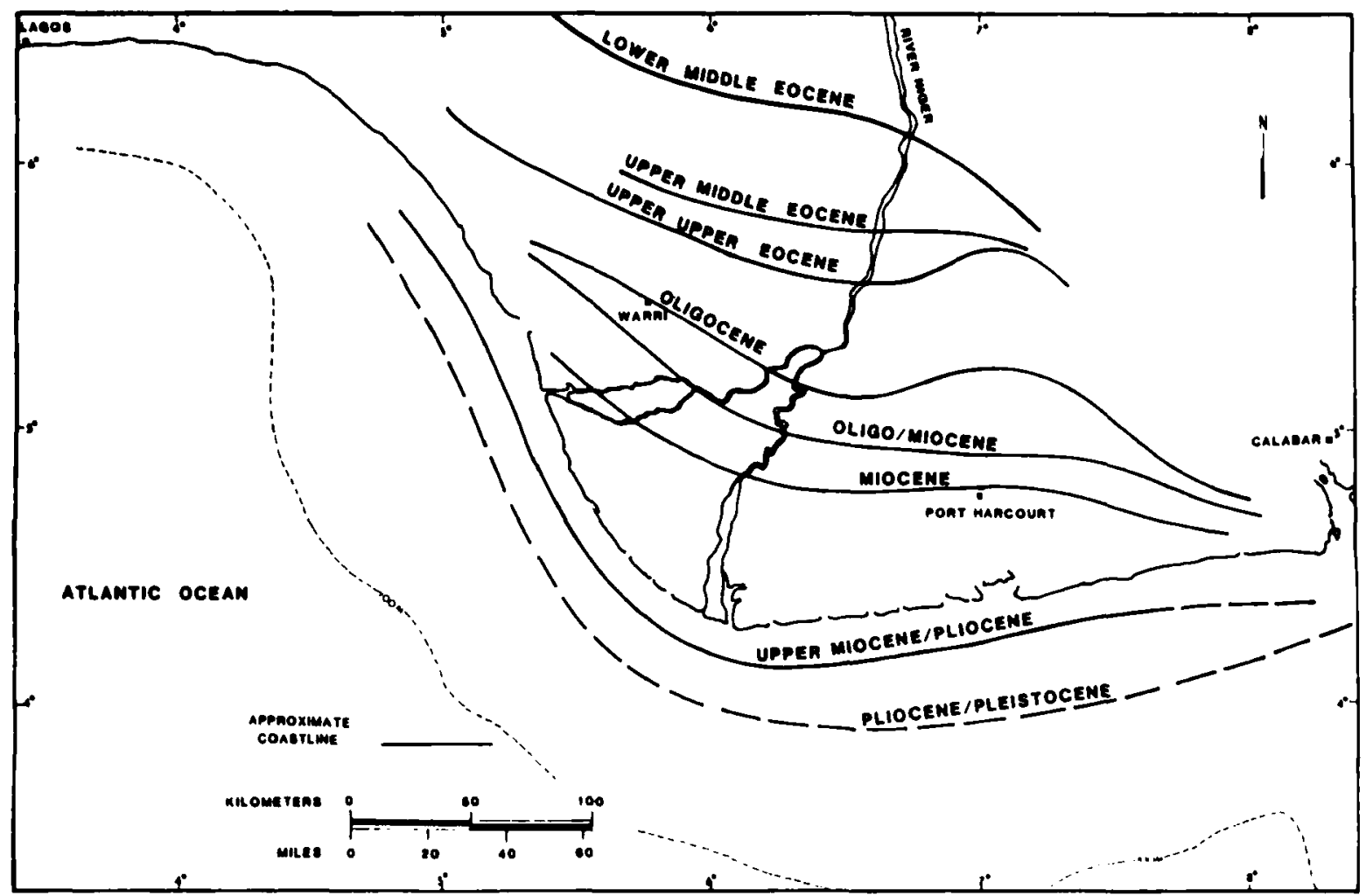

Fig. 3. Palaeogeography of the Tertiary Niger delta showing the stages of delta growth (after Short \& Stäuble 1967).

at some distance offshore in marine deposits. Inshore these high percentages $(>50 \%)$ are due to high concentrations of the Rhizophora pollen; further offshore they are due to low total pollen counts. Therefore, its quantitative distribution makes it a useful species for environmental interpretation (Muller \& Caratini, 1977).

Z. ramonae is frequent to abundant throughout most of the sequence described here, suggesting the presence of Rhizophora type mangrove swamp in the area. In the studied interval, the percentage varies from about $2 \%$ to more than $40 \%$ (Fig. 2). The absence or rarity of this species from some horizons indicates that deposition of those sediments occurred some distance from the mangrove edge.

Above approximately $1600 \mathrm{~m}$ the lithological analysis indicates a more continental influence which would fit with the advance of the delta front suggested by Short \& Stauble (1967). This is also suggested by the intermittent presence of the freshwater fern $M$. howardi.

Between $2680 \mathrm{~m}$ and about $3000 \mathrm{~m}$ the decrease in $Z$. ramonac could also indicate a more inland environment. However, Crassoretitriletes vanraadshooveni and Verrucatosporites usmensis are very common over this interval. Both species are considered to beclimbing ferns (Germeraad et al., 1968) and their abundance indicates a swamp forest area composed of non-Rhizophora type trees. The occurrence of $M$. hozuardi again suggests some freshwater influence and the presence of more open vegetation. Unfortunately the sampling intervals in this lower part are too great to determine the extent of this vegetation change very accurately.

Marine organisms are rare in the studied interval. This indicates that marine influence is very slight. This is further evidence that the high percentages of $Z$. ramonae mentioned above are due to deposition close to source, i.e., coastal deposition rather than the offshore transportation and concentration found by Muller (1959).

3. Organic matter. The accumulation and degradation of organic matter is related to surface conditions in the depositional environment and to diagenetic changes. Hence the presence or absence and abundance of different organic components can be directly related to lithofacies (Batten, 1981). It is also important to separate the characteristics that derive from the nature of the primary material of the sediments from those induced by subsequent diagenesis, differential migration and metamorphism (Staplin, 1969, p.50).

The organic matter in the samples recorded here consists of plant cuticles and wood fragments of a complete range of size from small to large. A long distance of transportation would have effected the sorting of the sizes as finer fractions tend to be deposited further offshore (Nwachukwu \& Barker, 1985). The varied range in these Nigerian samples indicates short distance transport, i.e. the source area for the sediments is the surrounding environment, and deposition in an area of variable energy where both coarse and finer particles settle out.

The colours of the organic matter types were determined, although organic matter colouration was not used in environmental interpretation,. The fragments of cuticles and wood are a mixture of colours, ranging from yellow to black. Normally, organic matter colour gets darker with increasing depth of burial. Therefore, the wide range of colour of organic 
fragments in these samples probably suggests that there has been reworking and subsequent oxidation in the paralic sequence. Additionally, the use of nitric acid for oxidation may have contributed to the wide range of colours in our samples. Reworking was easily established for some of the palynomorphs studied, especially when their ages were known. For example, a specimen of Cingulatisporites cf. ornatus, an Upper Cretaceous spore, was found in one assemblage. However, the occurrence of Cicatricosisporites dorogensis in these Miocene sediments, above the Oligocene range reported by Germeraad et al. (1968), was more difficult to dismiss as reworking as the sporesoccurred in several samples (see Fig. 2) and wereextremely well preserved. A common feature observed on many palynomorphs was corrosion; this results from oxidation and may indicate a degree of reworking of deltaic sediments. The plant debris in the sediments are terrestrially-derived types II and III organic matter (Bustin, 1988).

4. Lithology. Lithological studies of the borehole have dealt with the nature of the accessory minerals associated with the sediments (Oboh, 1987; Oboh \& Salami 1989). Pyrite, mica flakes, limonite stains, lignite streaks and heavy minerals were occasionally encountered in the sand bodies. The shales commonly contained pyrite and mica flakes and occasionally lignite, carbonaceous materials and glauconite. Of these accessory minerals, pyrite and glauconite are environmentally significant.

The common occurrence of pyrite in the shale bodies confirms the reducing conditions under which they were deposited. Glauconite is a typically marine mineral and although it was present in small amounts within unit $D$, its occurrence decreased from the base of the sequence. This shows that the sediments at the base of the succession are of transitional nature from marine influenced conditions.

\section{CONCLUSIONS}

Palynological and lithological evidence has been used to interpret the environment of deposition of the studied interval (11233583 metres). The range of size of organic matter (especially cuticles and wood fragments) indicates that the source of sediment is near the basin of deposition, although the colour range and presence of corroded palynomorphs show a degree of reworking. The marine influence, indicated by small amounts of glauconite within the shales of unit $D$, is strongest towards the base of this unit. The rarity of dinoflagellates in the sequence, however, shows the lack of marine depositional environments throughout the rest of the sampled section.

The frequent to abundant occurrence of $Z$. ramonae in most parts of the sequence suggests the presence of Rhizophora type mangrove swamp in the area. However, the percentages of $Z$. ramonae obtained in the present study seldom reach the very high levels quoted by Muller (1959) for the modern vegetation of the Orinoco delta environment.

The absence or rarity of $Z$. ramonae at some horizons in the Peregrinipollis nigericus and Clavamonocolpites sp. subzones suggests two periods of long term variation in the mangrove vegetation during the time of deposition. The interval of low frequency of $Z$. ramonae in the Middle Miocene corresponds with high percentages of climbing ferns indicative of swamp or marsh habitats (Germeraad et al., 1968). Such changes could be due to fluctuation in the species making up the coastal swamp forest or an advance of the delta front creating a more freshwater influence in the area of deposition. Towards the top of the studied sequence, in the Upper Miocene, $Z$. ramonae and the other pollen types become intermittent and the sedimenary environment more continental. This supports the view of Short \& Stäuble (1967) that the delta front advanced towards the end of the Miocene as deltaic sediments built up.

\section{ACKNOWLEDGEMENTS}

The authors wish to thank the Shell Petroleum Development Company of Nigeria Limited for permission to use their material from well Igbomotoru-1 and to publish these results. We are also grateful to M.A. Sowunmi, J.I. Nwachukwu and K.P.N. Kumaran for their comments and suggestions on an earlier version of the manuscript, Cambridge Earth Sciences Series No. 2300 .

\section{Manuscript received August 1991}

Manuscript accepted October 1991

\section{REFERENCES}

Adegoke, O.S. 1969. Eocene stratigraphy of southern Nigeria. Mem. Bur. Rech. Geolog. Min., 69, 23-49.

Allen, J.R.L. 1964. Sedimentation in the modern delta of the River Niger, West Africa. Sedimentology,1, 26-34.

Allen, J.R.L. 1965. Late Quaternary Niger delta and adjacent areas: sedimentary environments and lithofacies. Am. Assoc. Petrol. Geol. Bull., 49, 547-600

Asseez; L.O. 1976. Review of the stratigraphy, sedimentation and structure of the Niger delta. In Kogbe, C.A. (ed.), Geology of Nigeria, 259-272, Elizabethan Press, Lagos.

Batten, D.J. 1981. Palynofacies, organic maturation and source potential for petroleum. In Brooks, J. (ed.), Organic maturation studies and fossil fuel exploration, 201-223, Academic Press, London.

Biffi, U. and Grignani, D. 1983. Peridinioid dinoflagellate cysts from the Oligocene of the Niger delta. Micropalaeontology, 29 (2), 126-145.

Burke, K.C., Dessauvagie, T.F.J. and Whiteman, A.J. 1971. Opening of the Gulf of Guinea and geological history of the Benue depression and the Niger delta. Nature, 233, 51-55.

Burke, K.C., Dessauvagie, T.F.J. and Whiteman, A.J. 1972. Geological history of the Benue valley and adjacent areas. I $n$ Dessauvagie, T.F.J. and Whiteman, A.J. (eds), African Geology, 187-218, University of Ibadan Press.

Bustin, R.M. 1988. Sedimentology and characteristics of dispersed organic matter in the Tertiary Niger delta: origin of source rocks in a deltaic environment. Am. Assoc. Petrol. Geol. Bull., 72, 277-298.

Clarke, R.T. 1966. Peregrinipollis nigericus, a new palynomorph from the Upper Tertiary of Nigeria. Grana Palynol., 6 (3), 545-546.

Clarke, R.T. and Frederiksen, N.O. 1968. Some new sporomorphs from the Upper Tertiary of Nigeria. Grana Palynol., 8 (1), 210-224.

Ejedawe J.E. 1981. Patterns of incidence of oil reserves in Niger delta basin. Am.Assoc. Petrol.Geol. Bull., 65, 1574-1585.

Evamy, B.D., Haremboure, J., Kamerling, P., Knaap, W.A., Molloy, F.A. and Rowlands, P.H. 1978. Hydrocarbon habitat of Tertiary Niger delta. Am. Assoc. Petrol. Geol. Bull., 62, 1-39.

Frankl, E.J. and Cordry, E.A. 1967. The Niger delta province - recent developments onshore and offshore. Proc. $7 \mathrm{H} / \mathrm{h}$ World Petroleum Congress, 1(b), 195-209.

Germeraad, J.H., Hopping, C.A. and Muller, J. 1968. Palynology of Tertiary sediments from tropical areas. Rev. Palaeobot. Palynol., 6, 189348 . 
Jan du Chêne, R.E., Onyike, M.S. and Sowunmi, M.A. 1978. Some new Eocene pollen of the Ogwashi-Asaba Formation, southeastern Nigeria. Rev.Esp. de Micropal., 10(2), 285-322.

Jan du Chêne, R.E. and Salami, M.B. 1978. Palynology and micropaleontology of the Upper Eocene of the well Nsukwa-1 (Niger delta, Nigeria). C.R. des Séances, SPHN Geneve, 13(1), 5-9.

Knaap, W.A. 1971. A montane pollen species from the Upper Tertiary of the Niger delta. Niger. J. Mining and Geology, 6(11-2), 23-29.

Lambert-Aikhionbare, D.O. 1982. Relationship between diagenesis and pore fluid chemistry in Niger delta oil-bearing sands. I. Petrol. Geol., 4(3), 287-298.

Lambert-Aikhionbare, D.O. and Shaw, H.F. 1982. Significance of clays in the petroleum geology of the Niger delta. Clay Minerals, 17, 91-103.

Legoux, O. 1978. Quelques espèces de pollen caracteristiques du Néogène du Nigéria. Bull. Cent. Rech. Explor. - Production Elf Aquitaine, 2(2), 265317.

Merki, P. 1972. Structural geology of the Cenozoic Niger delta. In Dessauvagie, T.F.J. and Whiteman, A.J. (eds), African Geology, 635645, University of Ibadan Press.

Muller, J. 1959. Palynology of the Recent Orinoco delta and shelf sediments: Reports of the Orinoco shelf expedition, volume 5. Micropaleontology, 5(1), 1-32.

Muller, J. and Caratini, C. 1977. Pollen of Rhizophora (Rhizophoraceae) as a guide fossil. Pollen et Spores, 19(3), 361-389.

Murat, R.C. 1972. Stratigraphy and paleogeography of the Cretaceous and Lower Tertiary in southern Nigeria. In Dessauvagie, T.F.J. and Whiteman, A.J. (eds), African Geology, 251-266, University of Ibadan Press.

Nwachukwu, J.I. and Barker, C. 1985. Organic matter: size fraction relationships for recent sediments from theOrinoco Delta, Venezuela. Mar. Petrol. Geol. 2, 202-209.

Oboh, F.E. 1987. Biostratigraphy and paleoenvironmental analysis of strata penetrated by Igbomotoru-1 well, Niger delta. 106p. Unpublished M.Sc. thesis, University of Ife, Nigeria.
Oboh, F.E. and Salami, M.B. 1989. Lithostratigraphical and palynostratigraphical studies of Igbomotoru-1 well, Niger delta. $J$. African Earth Science, 9, (3-4), 531-540.

Odigi, M.I. 1987. Mineralogical and geochemical studies of Tertiary sediments from the eastern Niger delta and their relationship to petroleum occurrence. J. Petrol. Geol., 10(1), 101-114.

Ogbe, F.G.A. 1982. The biostratigraphy of the Niger delta, Nigeria. Niger. J. Mining and Geology, 18, 59-75.

Oomkens, E. 1974. Lithofacies relations in the Quaternary Niger delta complex. Sedimentology, 21, 195-222.

Petters, S.W. 1979. Nigerian Paleocene benthonic foraminiferal biostratigraphy, paleoecology and paleobiogeography. Marine Micropaleontology, 4, 85-95.

Short, K.C. and Stäuble, A.J. 1967. Outline of geology of Niger delta. Am. Assoc. Petrol. Geol. Bull., 51(5), 761-779.

Smith, A.G., Hurley, A.M. and Briden, J.C. 1981. Phanerozoic Paleocontinental World Maps. 102p. Cambridge University Press, Cambridge.

Sowunmi, M.A. 1973. A preliminary palynological study in the Rivers State, Nigeria. Oduma Magazine, 1(1), 13-14.

Sowunmi, M.A. 1981. Late Quaternary environmental changes in Nigeria. Pollen et Spores, 23(1), 125-148.

Staplin, F.L. 1969. Sedimentary organic matter, organic metamorphism and oil and gas occurrence. Bull.Can. Petrol. Geol., 17(1), 47-66.

Van Hoeken-Klinkenberg, P.M.J. 1964. A palynological investigation of some Upper Cretaceous sediments in Nigeria. Pollen et Spores, 6, 209 231.

Van Hoeken-Klinkenberg, P.M.J. 1966. Maestrichtian, Paleocene and Eocene pollen and spores from Nigeria. Leidse Geol. Meded., 38, 37-48.

Weber, K.J. 1971. Sedimentological aspects of oil fields in the Niger delta. Geologie en Mijnbouw, 50(3), 559-576.

Weber, K.J. and Daukoru, E. 1976. Petroleum geology of the Niger delta. Proc. 9th World Petroleum Congress, 2, 209-221. 